\title{
The Degree To Which Primary School Teachers In Amman Governorate Possess Soft Skills In Light Of Coronavirus Pandemic From Their Principals' Perspectives
}

\author{
${ }^{1}$ Dr. Fawaz Shehada, ${ }^{2}$ Sana' Al'ajrami , ${ }^{3}$ Rateb Al'ajrami
}

Article History: Received: 11 January 2021; Accepted: 27 February 2021; Published online: 5 April 2021

\begin{abstract}
Abstarct: The problem and the aim of the study: The rapid growth in technologies and the threat of COVID-19 pandemic have brought remarkable changes in the twenty-first century. Corona pandemic has caused a series of transformations in the different spheres of social, political, labor, economic and educational life. Different governments have launched emergency policy initiatives based on the suspension of classes and the closure of educational centers to continue teaching activities from homes through the use of information and communication, which led to the emergence of new skills that the teacher should possess in order to keep pace with modern developments and to continue with the student learning process. The primary school teacher is required to develop his soft skills with quality and efficiency, to be in line with the great technological renaissance the world is witnessing in the field of teaching, knowledge and culture, and to realize that one of his new tasks is to be a guide, facilitator and assistant for students to learn by themselves. Accordingly, the study aimed at finding out the degree to which primary school teachers in Amman Governorate, possess soft skills in light of Coronavirus pandemic from the viewpoint of their principals.

Research methods: The researcher reviewed the related literature to narrow the topic and aggregate the theoretical and empirical research related to the topic. The descriptive survey method was used in the study in addition to a 41- item questionnaire distinctly developed for gathering data. Reliability and validity of these items were checked by applying it to a pilot group of 30 principals selected randomly. (837) male and female principals from Amman governorate were selected as a study population. The sample of the study was (228) principals who were randomly selected, and constitutes $(27 \%)$ of the study population. The results of the study were obtained through appropriate statistical analyses, then analyzed and discussed according to the questions of the study.

Results: The results showed that the degree to which primary school teachers' possess soft skills was high. The results also indicated that there is a statistically significant difference according to gender variable in favor of females, while there are no statistically significant differences attributed to experience variable and the interaction between gender and experience.

Conclusion: the study pointed out that the importance of soft-skills for teachers has got more importance under COVID-19 pandemic crisis, as utilizing soft skills in teaching will improve the quality of educational results. There is a need to create awareness among the teachers about the importance of soft skills for career advancement and how to develop and practice such skills. schools should carefully review and incorporate the desired soft skills into their curricula. However, they should also continue running specialized training workshops to help teachers further improve their soft skills. It is equally important that teachers should also make efforts for improving their skills level through self-directed readings and participation in appropriate skills development programs and activities.
\end{abstract}

Key words: the degree of possession, soft skills, primary school teacher, corona pandemic.

\section{Introduction}

The history has witnessed that humanity went through several revolutions. The latest one is the revolution of information and communication that has touched human life considerably in the last century. With the emerging new technologies in the digital age, certainly, fostering high-quality teachers has been an essential aim of educational institutions which has perceived it indispensable to develop their capabilities, upgrade their standards and raise their professional competencies, in order to perform their multiple roles, follow up everything new in their field of work and stressthe importance of quality education for teachers of twenty-first century.

Technological developments have undergone a decisive transformation in a short period, imposing new requirements in all life aspects, one of which is teaching and learning. Education technology made learning more interactive and collaborative and helped teachers and students better engage with course material. Accordingly, the traditional role of teachers which focused on commensuration as the main source of information will have to change to improve the quality of education.

Teacher's role must be compatible with the changes of the digital age through upgrading his knowledge faster, offering up to date information to his students, discovering solutions to problems collaboratively and searching engines to find examples to enrich the content of his lessons, as he is one of the most important engines in the educational process, the positive guide for students in dealing with modern technology variables and the effective observer of the educational process through these modern technologies [1]. 
Teachers are considered one of the most important pillars of a successful educational process. They play a pivotal role in transferring knowledge, skills, information and experiences to students, and make them able to encounter all future challenges and difficulties.

In this regards, modern technology facilitated teachers' work and saved a lot of their time and effort. Furthermore, technology can help create a more immersive learning experience, automate many administrative tasks to shave a few minutes off a teacher's day while offering up valuable data around student performance and engagement with learning content. Therefore, teachers have to keep pace with modern technology, by possessing advanced skills to support students to have deeper and broader understanding in their learning [2].

However, Schools have to keep pace with technology and utilize its benefits in all educational aspects. They call for teachers to possess a set of skills needed in their work. Likewise, as rapid developments in technology integrate into our day-to-day lives, they affect the way teachers teach. Modern teachers need to be competent in not only basic skills but new skill sets, such as developing higher thinking skills, managing life skills, students' abilities, and educational technology. In addition to hard skills, teachers should master the art of teaching, and practice evaluation in an efficient way. This requires teachers to develop skills pre and post teaching experience, and achieve teaching goals efficiently and effectively [3]. Points out that teachers should apply technology as an alternate for the traditional method of teaching, and manage to incorporate it with their course designs and syllabus completely. They should become familiar with using smart devices, digital technologies, collaboration, communication, project-based learning, innovation, and multiple intelligences. Moreover, technology requires them to be academically, professionally and technically qualified, to enable them to practice teaching profession in an effective way, which contributes to building better future for learners, especially in light of Corona pandemic [4].

Coronavirus that first emerged a year ago swept across the world, and all countries have felt its destruction (joblessness, lockdowns, infirmity, constant fear and death). Consequently, Countries around the globe have imposed severe restrictions on their populations in a bid to stop the spread of this pandemic.Most of them have decided to temporarily close educational institutions, however, learning has not stopped but is now fully taking place online as schools and universities provide remote schooling. Most educational institutions cancelled in-person instruction and moved to remote learningas a strategic choice for this stage.

Therefore, the ministry of education has adopted ambitious development strategies and programs in order to implement the prioritized programs of the current phase as a means of communication to complete the distance education process. because the teacher is the leader of this stage, his development is considered the first block for the success of distance learning, and the achievement of maximum benefits for students, teachers have a role to stimulate and guide collaborative online learning among participants. On the other hand, the need for guidance with personal-emotional significance is amplifiedthrough online learning and frameworks without any face-to-face meetings [5].

Accordingly, teachers must be equipped with skills that enable them to interact positively with the quality of education imposed by the digital age to understand modern sciences and advanced technologies continuously, and to employ them optimally in the educational process.

In this regards, teachers should be provided with a set of skills called byeducators soft skills, such as communication skills, organization and planning, thinking skills, development, adaptation, flexibility, teamwork, crisis management and the ability to make decision which all covered in the study instrument.

Educators note that Coronavirus is an opportunity to change educational, economic, social, health and environmental models. In fact, it requires everyone to integrate digital solutions into the various processes. Because we live in a new, mysterious, complex, and unpredictable situation facing a very volatile enemy such as Coronavirus, it has become imperative that employees in general and teachers in particular possess the ability to transform and adapt, to the new situation. Corona pandemic also teaches us that it is not feasible to hire a person who is onlytechnically perfect, teachers should be able to interact with environment, adapt to different situations that they may encounter, and have the ability to manage stress, which give the importance to "soft skills" as considered a key factor to adaptwell and quickly to this complex and uncertain environment [6].

Soft skills are defined as "personal qualities that enhance personal interactions, job performance, and career prospects" [7]. also defined soft skills as "a set of personality traits related to communicating with others in an atmosphere of friendliness and cooperation and reflects a comfortable work environment. Soft skills are also related to the ability to express oneself and deal with the flows of digital data that have become required for everyone in the current era, such as computer skills, e-mail and social networks, in addition to the skills of presenting ideas in a persuasive manner [8]. defines soft skills as "aspects related to being tactful in conversation, having good appearance, and owning special qualities that distinguish the job applicant among his peers" [9]. defined soft skills as "the personal and professional skills and qualities that characterize a person's relationship with others [10].

The researchers define soft skills as a set of skills and abilities needed through living experiences and situations to enhance the social and professional integration. These skills are mainly based on the ability to 
communicate with others and interact with them in a positive way which leads to the development, progress and success of workplace.

Many educators indicate that soft skills can be taught or acquired even if they are not characteristics or qualities that teachers possess, skills such as communication and negotiation could be simply obtained through a professional trainer, or through self-training and then be developed gradually [11].

Soft skills are one of the sociological terms associated with personality tests, such as emotional intelligence tests, and related to teachers' personal and social characteristics, friendliness, communications and relationships with others. The importance of soft skills lies in making teachers more able to get jobs, commit strictly to time, adopt ethical methods and adhere to work ethics and organizational cultures, since they play a significant role in shaping teachers' personal structure. Moreover, soft skills are considered complementary to hard skills, they shall also contribute to raising the educational outcomes of the institution, and enhancing the teachers' competence, especially primary school teachers [12].

Pointed out to the need to equip everyone with soft skills in order to face the modern changes and serious challenges that characterize the current era and perform the assigned tasks entirely with reliability and honesty. Besides, soft skills cover all areas of life and supposed to achieve a successful coexistence, adaptation, flexibility in practical and personal life [13] [14].

Stated that soft skills affect every aspect of anyone's career and should be of value in any profession; since they are based on the individual's inner strength and personal competence, which will inevitably reflect on working harmoniously with others. He added that greater emphasis should be placed on the problem of soft skills lacking through being in touch with individuals possess them, and then teach these new skills to the people around us [15].

The most important soft skills mentioned by many specialists [15] [16] are:

Communication skills: are the abilities used to give and receive new ideas, feelings different kinds of information. They involve listening, speaking, observing and empathizing, dealing kindly with leaders and colleagues at work, and dealing politely with students. The concept of communication refers to communicate through face-to-face interactions, phone conversations and digital communications between oneself and others, to transfer ideas, experiences, knowledge and feelings accompanied by facial expressions and body language that have a positive impact on others. Communication skills are based on three basic components: sender, receiver and message. The researchers believe that communication skill is one of the most important skills required in light of Corona pandemic especially in remote work conditions imposed by the pandemic. It has become necessary to use the correct method of communication, whether inside or outside the work environment.

Planning and organization skills: are concerned with the ability to set priorities and start with the most important. Planning skill is a fundamental cognitive skill that forms part of our executive functions. It is predicting, preparing and thinking about the future through prior knowledge of what should be done to carry-out a task or reach a specific goal. Organizational skills are behavioral patterns utilized to stay focused on different tasks, and using time, energy, strength, mental capacity, physical space in order to achieve the desired outcome efficiently and effectively through arranging priorities, managing time, meeting deadlines and taking appropriate decisions. The researchers think that corona pandemic has exposed several fault lines and the traditional methods of planning and organizing in different sectors in general and in education sector in particular are no longer appropriate. It has become imperative in light of modern technology that individuals develop the skills which enable them to harness these technologies in their work aspects.

Development, adaptation, flexibility skills: refer to the individual's ability to invest in what's new and understanding the requirements of the work environment, such as working under pressure, working in culturally diverse environments and accepting criticism. In light of Corona pandemic, the researchers believe that the importance of these skills lies in the individual's awareness to work under pressure in different environments and circumstances, and to form teamwork and partnerships with others to reach the desired goals.

Teamwork: is a collaborative effort of a group working together cohesively, to achieve a common goal or to complete a task in the most effective and efficient way. It aims to solving problems and development. Working as a team is the catalyst for success, through concentration, planning, clarity, objectivity, avoiding individualism and communication. Working with others has become a necessity of life, whether in direct or indirect communication skills. Additionally, the ability to manage a group effectively requires building a team works consciously and follows the rules and instructions.

Thinking skills: are relatively specific cognitive operations that can be considered the building blocks of thinking, and based on making decisions about what should be done in a situation, generating ideas, thinking outside the box and criticizing constructively. The importance of thinking skills in the emerging circumstances is evident, as it may open the way for a positive impact on the individual's creativity, flexibility and intelligence.

Development and professionalism skills: refer to the teachers' ability to use the digital age skills in the work environment optimally and efficiently. The importance of development and professionalism 
skills in light of the Corona pandemic, results from the lack of prior attention to technological development that affected all life spheres, which therefore requires introducing technology deeply in life and education.

Negotiation skills: are critical teaching skills, and considered one of the important skills required in workplace situations. The teachers' ability to present, negotiate, and persuade ideas and information to their students in an acceptable manner by which compromise or agreement is reached while avoiding argument and dispute. The importance of negotiation skill in light of Corona pandemic has emerged due to the urgent need for good presentation, persuasion skills and creative marketing ideas.

Crisis management and the ability to make decisions: refers to the ability to understand and adapt to the requirements of the work environment. It is represented in problems solving skill, dealing with difficult situations and predicting the behavior of others. It is the teacher's ability to behave well, anticipate risks and problems and find appropriate solutions. In light of Corona pandemic, the importance of this skill lies in developing creative capacity and flexibility and taking the appropriate decision at the right time.

Emotional Intelligence: is the ability to understand our own feelings and the feelings of others. The concept of emotional intelligence means that a person possesses self-awareness that enables him to manage emotions properly. The emotionally intelligent teachers gain the ability to build relationships with students and adapt to everything around them, by building channels of harmony with those they work with. The importance of the emotional intelligence skill in light of the current pandemic comes through an individual's ability to understand people, dealing with them and trying to make them in his side which fosters a positive work environment.

Integrity: is the quality of being honest and having strong moral principles. It refers to teachers' firm adherence to a code of moral values at work, carrying out all the intended tasks, and accepting their own mistakes without passing the blame to others, because people respect who spend time doing their job really well more than those who escape mistakes and drop them on others. The importance of integrity skill stems from the need to diligent and hard employees who work honestly and commit to the work ethics.

Leadership skills: refer to leading within and beyond the classroom. More specifically, a set of skills demonstrated by teachers who continue to teach students but also have an influence that extends beyond their own classrooms to others within their own school and elsewhere, teachers influence students and direct their behaviors to achieve the goals set, by guiding them in performing the allocated tasks. The importance of leadership skills in light of Corona pandemic is highlighted by the need to set priorities and stop thinking in a binary way, as there are rarely two options in difficult situations. Leadership is useful in bringing the various parties together around shared objectives and cooperate to accomplish them.

Time management: is the thread running through almost all aspects of teaching, organizing the classroom, deciding how long and how often to teach various subjects, establishing a schedule includes the planned dates for starting and completing activities and keeping time-consuming behavior problems to a minimum. A skill which requires strength, firm commitment and strong determination. Due to this pandemic, and in the presence of technology, it is imperative to better manage time and invest it which can efficiently and effectively lead to a better performance.

Problem-solving skill: is a mental process helps in determining the source of a problem and finding solutions in effective and timely manners without any impediments. Problem-solving starts with identifying the issue, analyzing and evaluating situations, linking information and then making a decision by choosing the best solution at the right time. The importance of problem-solving skills in light of the Corona pandemic stems from the emergence of many problems that requires everyone to think differently during this pandemic, since the crisis imposed many changes in management styles and business models. This requires identifying, deconstructing and applying a strategy for solving the problem through clear communication with the concerned parties.

Balance: is one of the most important elements in achieving job success. Work-life balance refers to the level of priorities between personal and professional activities in an individual's life and the level to which activities related to their job are present in the home. No one can determine which balance style will suit the person, but it is important to strike a balance between performing the job and enjoying the private life. Balance is importance in achieving success, whether in the work of an individual or even in various aspects of life.

\section{Materials and methods}

The current study used the descriptive survey approach, whereby the degree to which primary school teachers in Amman governorate possess soft skills from their principals' perspectivesin light of Corona virus pandemic was measured, through an instrument prepared by the researchers after extracting its psychometric properties. To achieve the purpose of the study, (837) male and female principals from Amman governorate were selected as a study population. The sample of the study was (228) principals who were randomly selected, and constitutes $(27 \%)$ of the study population. Table 1 shows the distribution of the study sample according to its variables. 
Table 1 The distribution of the study sample according to its variables

\begin{tabular}{|c|c|c|c|c|}
\hline \# & \multicolumn{2}{|c|}{ Variable } & $\mathrm{N}$ & $\%$ \\
\hline \multirow{3}{*}{1} & \multirow{3}{*}{ Gender } & Male & 103 & 45.2 \\
\hline & & Female & 125 & 54.8 \\
\hline & & Total & 228 & 100.0 \\
\hline \multirow{4}{*}{2} & \multirow{4}{*}{$\begin{array}{c}\text { Years of } \\
\text { experience }\end{array}$} & Less than 5 & 72 & 31.6 \\
\hline & & $5-10$ & 77 & 33.8 \\
\hline & & More than 10 & 79 & 34.6 \\
\hline & & Total & 228 & 100.0 \\
\hline
\end{tabular}

\section{Literature review}

Carried out a study aimed to determine the relationship between soft and technical skills that technology workers should possess to reach career success. The descriptive approach was used and a questionnaire applied to a sample of technology workers. The results showed that there were five important soft skills technology workers should possess: dealing with people, time management, paying attention to detail, integrity, innovation and design [17].

investigated the reality of soft skills for individuals seeking work. The study used the descriptive and analytical approach and a questionnaire used as a scale. The study sample consisted of (254) job applicants. The results showed that the CVs of most job seekers consist of a combination of soft skills [18].

Conducted a study to identify the degree to which directors working in Jordanian universities possess soft skills. The study used the descriptive approach and a questionnaire developed to verify the goal. The study sample consisted of (288) directors working in Jordanian universities. The results showed that directors possess soft skills in differing proportions [19].

Carried out a study to demonstrate the importance of soft skills in the future. The study used the descriptive and analytical approach, and a questionnaire as an instrument to measure the study variables. The sample of the study consisted of (250) male and female students. The results indicated that the students' practical skills competencies should be improved. Also, there was no statistically significant difference related to the marital status variable [20].

Clarified the importance of soft skills for university students after graduation to better prepare them for the labor market. The study used the descriptive approach and a questionnaire used as a measure instrument. The most prominent results showed the great role that soft skills play in building and refining students' personality in their lives in general and their professional ones in particular.The result also assured that students should arm themselves with soft skills, besides their academic and technical studies [21].

Conducted a study aimed at identifying the soft skills of public school principals in the education directorate of Southern Shuna. The study used the descriptive survey approach, and a questionnaire used as a measure instrument. The study sample consisted of (489) male and female teachers who were randomly selected. The results of the study showed that there were no statistically significant differences attributed to the variables of gender, marital status, age, scientific qualification and years of experience [22].

Examined the relationship between soft skills and entrepreneurial attitudes among students of technical and vocational colleges in Gaza governorates. The study used the descriptive approachand a questionnaire used as a scale. The sample consisted of (388) male and female students. The results revealed a statistically significant relationship between soft skills and entrepreneurial attitudes among college students [23].

A good body of research, which varied in scope and objectives, was reviewed for the purpose of the study. Soft skills related studies [17] [18] [20] [21] pointed out to the importance of soft skills for job applicants.

Another studies [19] [20] have indicated the degree to which directors possess soft skills [23] investigated the nature of the relationship between soft skills and entrepreneurial attitudes.

The current study aimed to investigate the degree to which elementary school teachers in Amman governorate possess soft skills from theviewpoint of their principals.

The previous studies varied in terms of method and instrument used. The current study agreed with [22] [23] and the [19]. in their use of the descriptive approach and the questionnaire as a study instrument, and differed somewhat fromother studies in using the descriptive analytical method, like [20].

The current study benefited from previous studies in presenting and enriching the theoretical literature, developing the study instrument, determining the methodology used and in discussing the results.

To the best of the researchers' knowledge, this study is the first of its kind to examine the degree to which primary school teachers in the Amman governorate possess soft skills from the viewpoint of their principals. 


\section{Research program}

Based on an extensive review of the literature [18] [19] [20] [22] [23].

and to achieve the objectives of the study, a questionnaire was developed to measure the degree to which primary school teachers in Amman governorate possess soft skills,. It consisted of (41) paragraphs. 5point likert scale was used which responders specify their level of agreement to a statement typically in five points: (1) Strongly disagree; (2) Disagree; (3) Neutral; (4) Agree; (5) Strongly agree. In order to examine the validity of the instruments, a panel of educational experts reviewed the instruments. The team was asked to validate the content of the instruments concerning the instrument's items, appropriateness and suitability to the purposes of the current study, the language clarity, and how well they represent soft skills. The teams' comments and recommendations were studied carefully and taken into account in amending the final version of the instrument. The correlation coefficients for the instrument items were also calculated as shown in Table 2.

Table 2 The correlation coefficients of the instrument items

\begin{tabular}{|c|c|c|c|c|c|c|c|}
\hline $\begin{array}{c}\text { Item } \\
\text { no }\end{array}$ & Correlation & $\begin{array}{c}\text { Item } \\
\text { no }\end{array}$ & Correlation & $\begin{array}{c}\text { Item } \\
\text { no }\end{array}$ & Correlation & $\begin{array}{c}\text { Item } \\
\text { no }\end{array}$ & Correlation \\
\hline 1 & 0.51 & 12 & 0.60 & 23 & 0.44 & 34 & 0.37 \\
\hline 2 & 0.60 & 13 & 0.53 & 24 & 0.64 & 35 & 0.39 \\
\hline 3 & 0.62 & 14 & 0.67 & 25 & 0.67 & 36 & 0.74 \\
\hline 4 & 0.49 & 15 & 0.58 & 26 & 0.71 & 37 & 0.71 \\
\hline 5 & 0.55 & 16 & 0.55 & 27 & 0.73 & 38 & 0.38 \\
\hline 6 & 0.52 & 17 & 0.64 & 28 & 0.61 & 39 & 0.45 \\
\hline 7 & 0.63 & 14 & 0.60 & 29 & 0.70 & 40 & 0.39 \\
\hline 4 & 0.65 & 15 & 0.69 & 30 & 0.42 & 41 & 0.37 \\
\hline 5 & 0.69 & 20 & 0.60 & 31 & 0.60 & & \\
\hline 10 & 0.65 & 21 & 0.73 & 32 & 0.67 & & \\
\hline 11 & 0.67 & 22 & 0.52 & 33 & 0.71 & & \\
\hline
\end{tabular}

The reliability of the questionnaire was tested and refined through test-retest method on a pilot group of 30 principals selected randomly and left out later from the sample of the study. The participating principals were asked to fill the questionnaire twice within a two-week interval. Pearson correlation coefficient was calculated between the two times and ranged between $(0.68-0.81)$. Internal consistency was tested, Cronbach alpha was found as $(0.74-0.85)$ that was considered suitable to conduct the study.

The researchers developed a questionnaire on a five-point scale (strongly agree, agree, undecided, disagree, strongly disagree with the numerical values of five, four, three, two and one respectively). Thus, the scores on the study instrument ranged between (41) degrees, which represent the lowest degree that the subject can obtain, and (205) degree, which represents the highest score, while the average of the scale represents (123) degrees.

The principals' responses were analyzed in terms of the five Likert scale; which was further categorized into three levels: High, intermediate, and Low degrees. Mean scores were valued against the following criteria: (1.00 - 2.33 as Weak; 2.34 - 3.67 as intermediate; 3.68 - 5.00 as Strong). The percentage was calculated according to the following equation: The highest value - The lowest value/category number. In the present research, the highest value was 5; the lowest value was 1 ; and the category numbers were 3 . Thus, the appropriate degree was calculated as follows: $5-1 / 3=1.33$ as shown in Table 3 .

Table 3 Class intervals of the degree to which elementary school teachers in Amman governorate possess soft skills

\begin{tabular}{|c|c|}
\hline Class intervals & Class \\
\hline $1-2,33$ & low \\
\hline $2.34-3.67$ & medium \\
\hline $3.68-5.00$ & high \\
\hline
\end{tabular}

In order to find out the degree to which primary school teachers in Amman Governorate possess soft skills, means and standard deviations of the study sample scores were calculated using SPSS statistics. To examine if there are any statistically significance differences attributed to gender (male, female) and experience (less than 5 years, 5-10 years, more than 10) in the degree to which primary school teachers in Amman governorate possess soft skills, two-way analysis of variance and multi analysis of variance were used. 


\section{Research results}

The first research question of the study sought the degree to which primary school teachers in Amman Governorate possess soft skills in light of Corona virus pandemic from their principals' perspectives. In order to answer this question, a fill-in self-reported questionnaire was developed on a five-point scale (strongly agree, agree, undecided, disagree, strongly disagree with the numerical values of five, four, three, two and one respectively). A quantitative analysis was conducted to interpret the results obtained through the questionnaire, as shown in Table 4.

Table 4 Means and standard deviations of the study instrument' domains and the overall score of the scale

\begin{tabular}{|l|c|c|c|c|c|}
\hline$\#$ & Domain & Mean & $\begin{array}{c}\text { Standard } \\
\text { deviation }\end{array}$ & Rank & Degree \\
\hline 1 & Communication & 3.94 & 0.59 & 1 & high \\
\hline 2 & planning and Organization & 3.84 & 0.67 & 2 & high \\
\hline 3 & $\begin{array}{c}\text { Development, adaptation, } \\
\text { flexibility and teamwork }\end{array}$ & 3.65 & 0.68 & 5 & medium \\
\hline 4 & thinking skills & 3.71 & 0.69 & 4 & high \\
\hline 5 & $\begin{array}{c}\text { Crisis management and the } \\
\text { ability to make decisions }\end{array}$ & 3.78 & 0.68 & 3 & High \\
\hline
\end{tabular}

Table 4 depicts the mean scores and standard deviations of questions assessing the degree to which primary school teachers in Amman Governorate possess soft skills. The highest score was given for the item "communication" with a mean score of (3.94) and standard deviation of (0.59), followed by " planning and organization" which ranked second with a mean score of (3.84), and a standard deviation of (0.67). "Crisis management and the ability to make decisions" ranked thirdwith a mean of (3.78) and a standard deviation of (0.68). "Thinking skills" ranked fourth with a mean of (3.71), and a standard deviation of (0.69). On the other hand, the "development, adaptation, flexibility and team work" received the lowest scored and ranked last with a mean score of (3.65) and a standard deviation of (0.68). The average response of the study sample on the scale as a whole got a mean score of (3.77), and a standard deviation of (0.62). follows:

Means and standard deviations of the responses on the items of each domain were calculated as

1- Communication : The means and standard deviations scores for the responses on the items of communication domain were calculated as shown in Table 5.

Table 5 Means and standard deviations scores for the responses on the items of the communication domain

\begin{tabular}{|c|c|c|c|c|c|}
\hline$\#$ & Items & Mean & Standard deviation & Item rank & Degree \\
\hline 1 & $\begin{array}{c}\text { taking into account good grooming and } \\
\text { tidy appearance as a good example for } \\
\text { students }\end{array}$ & 4.22 & 0.64 & 1 & High \\
\hline 2 & $\begin{array}{l}\text { speaking sweetly, using successful } \\
\text { dialogue techniques and employing body } \\
\text { language in a thoughtful way that } \\
\text { influences students and others }\end{array}$ & 4.02 & 0.75 & 2 & High \\
\hline 3 & $\begin{array}{l}\text { expressing the idea clearly and listens well } \\
\text { to others }\end{array}$ & 4.02 & 0.69 & 2 & High \\
\hline 4 & $\begin{array}{l}\text { using the strong and calm personality in } \\
\text { learning and teaching }\end{array}$ & 3.96 & 0.78 & 3 & High \\
\hline 5 & $\begin{array}{l}\text { adequate knowledge of the nature of } \\
\text { students and parents }\end{array}$ & 3.80 & 0.84 & 5 & High \\
\hline 6 & $\begin{array}{c}\text { The ability to build a strong relationship } \\
\text { between him and the students outside the } \\
\text { classroom }\end{array}$ & 3.67 & 0.88 & 6 & High \\
\hline 7 & $\begin{array}{l}\text { the ability to communicate information in } \\
\text { many different ways that are interesting } \\
\text { and attractive to others }\end{array}$ & 3.91 & 0.82 & 4 & High \\
\hline & The total score for the domain & 3.94 & 0.59 & & High \\
\hline
\end{tabular}


Table 5 shows that the highest score was given to the first item " taking into account good grooming and tidy appearance as a good example for students " with a mean of (4.22) and a standard deviation of (0.64), while the lowest score was given sixth item "The ability to build a strong relationship between him and the students outside the classroom " with a mean of (3.67) and a standard deviation of (0.88).

2- Planning and organization: The means and standard deviations scores for the responses on the items of planning and organization domain were calculated as shown in Table 6.

Table 6 Means and standard deviations scores for the responses on the items of the planning and organization domain

\begin{tabular}{|c|c|c|c|c|c|}
\hline$\#$ & Items & Mean & $\begin{array}{l}\text { Standard } \\
\text { deviation }\end{array}$ & Item rank & Degree \\
\hline 1 & $\begin{array}{l}\text { has the ability to define his goals that he wants to } \\
\text { reach }\end{array}$ & 4.01 & 0.75 & 1 & High \\
\hline 2 & $\begin{array}{l}\text { Possesses the skill of planning and pre-setting for } \\
\text { goals }\end{array}$ & 3.93 & 0.79 & 2 & High \\
\hline 3 & $\begin{array}{l}\text { possesses skills that make him capable of } \\
\text { developing, improving and implementing }\end{array}$ & 3.86 & 0.83 & 4 & High \\
\hline 4 & $\begin{array}{l}\text { has high organizational skills in dialogue } \\
\text { management through distance learning, } \\
\text { overcoming any difficulties as much as possible }\end{array}$ & 3.68 & 0.94 & 7 & High \\
\hline 5 & $\begin{array}{c}\text { Has the ability to manage work, prioritize tasks } \\
\text { and utilize available resources to simplify the } \\
\text { lesson }\end{array}$ & 3.89 & 0.77 & 3 & High \\
\hline 6 & $\begin{array}{l}\text { Has deep regard and interest for each student, and } \\
\text { caters for individual differences }\end{array}$ & 3.81 & 0.84 & 5 & High \\
\hline 7 & $\begin{array}{l}\text { works to form a team to achieve specific goals } \\
\text { and promote team spirit among them }\end{array}$ & 3.69 & 0.93 & 6 & High \\
\hline & The total score for the domain & 3.84 & 0.67 & & High \\
\hline
\end{tabular}

Table 6 shows that the highest score was given to the first item " has the ability to define his goals that he wants to reach " with a mean of (4.01) and a standard deviation of (0.75), while the lowest score was given fourth item " has high organizational skills in dialogue management through distance learning, overcoming any difficulties as much as possible " with a mean of (3.68) and a standard deviation of (0.94).

3- Development, adaptation, flexibility and teamwork: The means and standard deviations scores for the responses on the items of the this domain were calculated as shown in Table 7.

Table 7 Means and standard deviations scores for the responses on the items of development, adaptation, flexibility and teamwork domain

\begin{tabular}{|l|c|c|c|c|c|}
\hline$\#$ & Items & Mean & $\begin{array}{c}\text { Standard } \\
\text { deviation }\end{array}$ & Item rank & Degree \\
\hline 1 & Can make decisions about the current \\
situation & $\begin{array}{c}\text { asked } \\
\text { aumbly offers logical solutions when }\end{array}$ & 3.81 & 0.81 & 2 & High \\
\hline 3 & $\begin{array}{c}\text { Learn new methods of assessing students, } \\
\text { either individually or in groups }\end{array}$ & 3.78 & 0.77 & 3 & High \\
\hline 4 & $\begin{array}{c}\text { always strives to develop himself } \\
\text { professionally through active participation } \\
\text { in training courses and by consulting } \\
\text { those with experience }\end{array}$ & 3.73 & 0.91 & 5 & High \\
\hline 5 & $\begin{array}{c}\text { Establish healthy parent-school } \\
\text { relationships }\end{array}$ & 3.54 & 0.95 & 7 & Medium \\
\hline 6 & $\begin{array}{c}\text { cooperates with the school in providing } \\
\text { courses for parents if needed }\end{array}$ & 3.33 & 1.14 & 9 & Medium \\
\hline 7 & $\begin{array}{c}\text { Identifies his skills and compares them to } \\
\text { those required for professional growth }\end{array}$ & 3.52 & 0.89 & 8 & Medium \\
\hline 8 & flexible with those who oppose his & 3.59 & 0.83 & 6 & Medium \\
\hline
\end{tabular}




\begin{tabular}{|l|c|c|c|c|c|}
\hline & thinking & & & & \\
\hline 9 & Possesses self-control skills & 3.77 & 0.79 & 4 & High \\
\hline & The total score for the domain & 3.65 & 0.68 & & High \\
\hline
\end{tabular}

Table 7 shows that the item "humbly offers logical solutions when asked" ranked first with a mean of (3.81) and a standard deviation of (0.77), while the item "cooperates with the school in providing courses for parents if needed" ranked last with a mean of (3.33) and a standard deviation of (1.14).

4- Thinking skills: The means and standard deviations scores for the responses on the items of the thinking skills domain were calculated as shown in Table 8.

Table 8 Means and standard deviations scores for the responses on the items of the thinking skills domain

\begin{tabular}{|c|c|c|c|c|c|}
\hline \# & Items & Mean & $\begin{array}{l}\text { Standard } \\
\text { deviation }\end{array}$ & Item rank & Degree \\
\hline 1 & Stimulates thinking & 3.83 & 0.79 & 4 & High \\
\hline 2 & $\begin{array}{l}\text { Encouraged students to search } \\
\text { for information and solve } \\
\text { problems }\end{array}$ & 3.71 & 0.84 & 6 & High \\
\hline 3 & $\begin{array}{c}\text { Possesses thinking } \\
\text { management skills, and uses } \\
\text { them effectively to derive ideas } \\
\text { from his students }\end{array}$ & 3.68 & 0.85 & 8 & High \\
\hline 4 & $\begin{array}{c}\text { Employs higher order thinking } \\
\text { skills }\end{array}$ & 3.53 & 0.90 & 10 & Medium \\
\hline 5 & $\begin{array}{c}\text { Has the power to raise } \\
\text { questions }\end{array}$ & 3.85 & 0.72 & 3 & High \\
\hline 6 & $\begin{array}{l}\text { Possesses constructive debating } \\
\text { skills by proposing new } \\
\text { alternatives }\end{array}$ & 3.73 & 0.84 & 5 & High \\
\hline 7 & $\begin{array}{l}\text { Has the ability to distinguish } \\
\text { between fact and opinion }\end{array}$ & 3.86 & 0.73 & 2 & High \\
\hline 8 & $\begin{array}{l}\text { Listens to others with interest, } \\
\text { focus, and a understand what } \\
\text { they want to achieve }\end{array}$ & 3.88 & 0.74 & 1 & High \\
\hline$\overline{9}$ & $\begin{array}{c}\text { Creates new and creative ideas } \\
\text { to develop work in all fields } \\
\text { and aspects }\end{array}$ & 3.68 & 0.91 & 8 & High \\
\hline 10 & $\begin{array}{l}\text { Look for details to manage } \\
\text { tasks effectively }\end{array}$ & 3.70 & 0.85 & 7 & High \\
\hline 11 & $\begin{array}{l}\text { Analyzes the behavior of those } \\
\text { he wants to influence and } \\
\text { negotiate with }\end{array}$ & 3.56 & 0.93 & 9 & Medium \\
\hline 12 & $\begin{array}{l}\text { Dazzles his students by } \\
\text { presenting an idea or issue } \\
\text { every day for discussion, to } \\
\text { find out what is new }\end{array}$ & 3.51 & 0.95 & 11 & Medium \\
\hline & The total score for the domain & 3.71 & 0.69 & & High \\
\hline
\end{tabular}

Table 8 shows that the item " Listens to others with interest, focus, and a understand what they want to achieve " ranked first with a mean of (3.88) and a standard deviation of (0.74), while the item " Dazzles his students by presenting an idea or issue every day for discussion, to find out what is new " ranked last with a mean of (3.51) and a standard deviation of (0.95).

5- Crisis management and the ability to make decisions: The means and standard deviations scores for the responses on the items of this domain were calculated as shown in Table 9.

Table 9 Means and standard deviations scores for the responses on the items of the crisis management and the ability to make decisions domain 
The Degree To Which Primary School Teachers In Amman Governorate Possess Soft Skills In Light Of Coronavirus Pandemic From Their Principals' Perspectives

\begin{tabular}{|l|c|c|c|c|c|}
\hline$\#$ & Items & Mean & $\begin{array}{c}\text { Standard } \\
\text { deviation }\end{array}$ & Item rank & Degree \\
\hline 1 & Uses his previous experiences in various life \\
situations & 3.85 & 0.76 & 1 & High \\
\hline 2 & Acts wisely in difficult and critical situations & 3.77 & 0.80 & 3 & High \\
\hline 3 & quick-witted & 3.77 & 0.77 & 3 & High \\
\hline 4 & $\begin{array}{c}\text { shoulders the responsibilities assigned to him and } \\
\text { patient with long work periods }\end{array}$ & 3.76 & 0.88 & 4 & High \\
\hline 5 & $\begin{array}{c}\text { provides alternative and appropriate suggestions } \\
\text { for the problems facing students or parents }\end{array}$ & 3.71 & 0.84 & 5 & High \\
\hline 6 & $\begin{array}{c}\text { has the ability to deal efficiently with the rapid } \\
\text { changes taking place in his work }\end{array}$ & 3.80 & 0.80 & 2 & High \\
\hline & The total score for the domain & 3.78 & 0.68 & & High \\
\hline
\end{tabular}

Table 9 shows that the highest score was given to the first item " Uses his previous experiences in various life situations " with a mean of (3.85) and a standard deviation of (0.76), while the lowest score was given fifth item " provides alternative and appropriate suggestions for the problems facing students or parents " with a mean of (3.71) and a standard deviation of (0.84).

The second question sought if there are any statistically significant differences at $(\alpha=0.05)$ in the degree to which science teachers in Amman governorate possess soft skills from the viewpoint of their principals due to variables (gender, years of experience and their interaction). To answer this question, a twoway ANOVA test was performed for the responses of results of the second question. Table (10) shows the means and standard deviations of the degree to which primary school teachers in Amman governorate possess soft skills from the viewpoint of their principals according to gender and years of experience.

Table 10 The means and standard deviations of the degree to which primary school teachers in Amman governorate possess soft skills from the point of view of their principals according to gender and years of experience

\begin{tabular}{|c|c|c|c|c|c|c|c|c|c|}
\hline \multirow{3}{*}{ Skill } & \multirow{3}{*}{ gender } & \multicolumn{8}{|c|}{ Experience } \\
\hline & & \multicolumn{2}{|c|}{ Less than 5} & \multicolumn{2}{|c|}{$5-10$} & \multicolumn{2}{|c|}{ More than 10} & \multicolumn{2}{|c|}{ Total } \\
\hline & & Mean & $\mathrm{SD}$ & Mean & $\mathrm{SD}$ & Mean & SD & Mean & $\overline{S D}$ \\
\hline \multirow{3}{*}{ Communication } & Male & 3.84 & 0.64 & 3.90 & 0.57 & 3.92 & 0.54 & 3.89 & 0.58 \\
\hline & Female & 3.92 & 0.60 & 4.05 & 0.59 & 3.99 & 0.60 & 3.99 & 0.59 \\
\hline & Total & 3.88 & 0.62 & 3.98 & 0.58 & 3.96 & 0.58 & 3.94 & 0.59 \\
\hline \multirow{3}{*}{$\begin{array}{l}\text { planning and } \\
\text { Organization }\end{array}$} & Male & 3.76 & 0.64 & 3.74 & 0.69 & 3.76 & 0.69 & 3.75 & 0.66 \\
\hline & Female & 3.84 & 0.66 & 3.93 & 0.65 & 3.95 & 0.69 & 3.91 & 0.66 \\
\hline & Total & 3.80 & 0.65 & 3.85 & 0.67 & 3.86 & 0.69 & 3.84 & 0.67 \\
\hline \multirow{3}{*}{$\begin{array}{l}\text { Development, } \\
\text { adaptation, } \\
\text { flexibility and } \\
\text { teamwork }\end{array}$} & Male & 3.47 & 0.70 & 3.52 & 0.67 & 3.64 & 0.69 & 3.55 & 0.68 \\
\hline & Female & 3.69 & 0.65 & 3.71 & 0.69 & 3.81 & 0.68 & 3.74 & 0.67 \\
\hline & Total & 3.59 & 0.68 & 3.63 & 0.68 & 3.73 & 0.68 & 3.65 & 0.68 \\
\hline \multirow{3}{*}{ Thinking skills } & Male & 3.59 & 0.73 & 3.59 & 0.69 & 3.62 & 0.69 & 3.60 & 0.70 \\
\hline & Female & 3.80 & 0.67 & 3.81 & 0.67 & 3.79 & 0.68 & 3.80 & 0.67 \\
\hline & Total & 3.70 & 0.70 & 3.71 & 0.68 & 3.72 & 0.69 & 3.71 & 0.69 \\
\hline \multirow{3}{*}{$\begin{array}{l}\text { Crisis management } \\
\text { and the ability to } \\
\text { make decisions }\end{array}$} & Male & 3.59 & 0.67 & 3.59 & 0.70 & 3.66 & 0.67 & 3.61 & 0.67 \\
\hline & Female & 3.85 & 0.73 & 3.92 & 0.65 & 3.95 & 0.64 & 3.91 & 0.67 \\
\hline & Total & 3.73 & 0.71 & 3.77 & 0.68 & 3.82 & 0.67 & 3.78 & 0.68 \\
\hline \multirow{3}{*}{$\begin{array}{l}\text { Soft skills as a } \\
\text { whole }\end{array}$} & Male & 3.64 & 0.64 & 3.65 & 0.61 & 3.71 & 0.63 & 3.67 & 0.62 \\
\hline & Female & 3.81 & 0.62 & 3.87 & 0.62 & 3.88 & 0.61 & 3.85 & 0.61 \\
\hline & Total & 3.73 & 0.63 & 3.77 & 0.62 & 3.80 & 0.62 & 3.77 & 0.62 \\
\hline
\end{tabular}

Table (10) shows apparent differences in mean scores according to gender and years of experience variables in the total degree of soft skills, and to know their effect, the two-way ANOVA test was performed, as shown in Table 11 
Table 11 Results of the two-way ANOVA test for the effect of gender and years of experience and their interaction on the overall soft skills score

\begin{tabular}{|l|l|c|c|c|c|c|}
\hline$\#$ & \multicolumn{1}{|c|}{ source } & $\begin{array}{c}\text { Type sum of } \\
\text { squares }\end{array}$ & $\mathrm{df}$ & Mean square & $\mathrm{F}$ & Siq (P) \\
\hline 1 & Gender & 1.964 & 1 & 1.964 & 5.110 & 030.0 \\
\hline 2 & Experience & .176 & 2 & .0880 & .2300 & 800. \\
\hline 3 & Interaction & .020 & 2 & .0100 & .0260 & 0.970 \\
\hline 4 & Error & 85.322 & 222 & .3840 & & \\
\hline 5 & Total & 87.515 & 227 & & & \\
\hline
\end{tabular}

Statistically significant at $(\alpha=0.05)$

Table 11 indicates that there are statistically significant differences $(\alpha=0.05)$ in the total score of soft skills according to gender variable, ANOVA table gives $\mathrm{F}$ statistics $=5.11, \mathrm{p}=0.003$; which is a statistically significant value at $(\alpha=0.05)$. It is noted that the female mean (3.85) was superior to the male (3.67). The results also indicate that there are no statistically significant differences at $(\alpha=0.05)$ in the total degree of soft skills attributed to the years of experience or the interaction between gender and experience.

There were observed differences among the means of the respondents' scores according to gender and years of experience variables. To investigate whether these differences are statistically significant, 2-way MANOVA test was performed as shown in Table 12 .

Table 12 Results of the 2-way MANOVA test for the effect of gender, years of experience and their interaction on soft skills

\begin{tabular}{|c|c|c|c|c|c|c|c|}
\hline Source & No & Variables & $\begin{array}{l}\text { Type sum } \\
\text { of squares }\end{array}$ & $\mathrm{df}$ & $\begin{array}{l}\text { Mean } \\
\text { square }\end{array}$ & $\mathrm{F}$ & $\operatorname{Siq}(\mathrm{P})$ \\
\hline \multirow{5}{*}{$\begin{array}{l}\text { Gender } \\
\text { Wilks' } \\
\text { Lambda } \\
\text { Value }=.94 \\
\text { F }=3.02 \\
\text { DF }=5\end{array}$} & 1 & Communication & .543 & 1 & .543 & 1.544 & 0.22 \\
\hline & 2 & planning and Organization & 1.361 & 1 & 1.361 & 3.034 & 0.08 \\
\hline & 3 & $\begin{array}{l}\text { Development, adaptation, } \\
\text { flexibility and teamwork }\end{array}$ & 1.989 & 1 & 1.989 & 4.295 & 0.04 \\
\hline & 4 & Thinking skills & 2.343 & 1 & 2.343 & 4.955 & 0.03 \\
\hline & 5 & $\begin{array}{l}\text { Crisis management and the } \\
\text { ability to make decisions }\end{array}$ & 4.809 & 1 & 4.809 & 10.561 & 0.00 \\
\hline \multirow{5}{*}{$\begin{array}{l}\text { Experience } \\
\text { Wilks' } \\
\text { Lambda } \\
\text { Value }=.95 \\
F \quad=1.074 \\
\text { DF }=5\end{array}$} & 1 & Communication & .365 & 2 & .183 & .520 & 0.60 \\
\hline & 2 & planning and Organization & .096 & 2 & .048 & .107 & 0.90 \\
\hline & 3 & $\begin{array}{l}\text { Development, adaptation, } \\
\text { flexibility and teamwork }\end{array}$ & .874 & 2 & .437 & .943 & 0.39 \\
\hline & 4 & Thinking skills & .005 & 2 & .002 & .005 & 0.99 \\
\hline & 5 & $\begin{array}{l}\text { Crisis management and the } \\
\text { ability to make decisions }\end{array}$ & .267 & 2 & .134 & .294 & 0.75 \\
\hline \multirow{5}{*}{$\begin{array}{l}\text { Interaction } \\
\text { Wilks' } \\
\text { Lambda } \\
\text { Value }=.98 \\
F \quad=.397 \\
\text { DF }=10\end{array}$} & 1 & Communication & .080 & 2 & .040 & .114 & 0.89 \\
\hline & 2 & planning and Organization & .182 & 2 & .091 & .202 & 0.82 \\
\hline & 3 & $\begin{array}{l}\text { Development, adaptation, } \\
\text { flexibility and teamwork }\end{array}$ & .030 & 2 & .015 & .033 & 0.97 \\
\hline & 4 & Thinking skills & .038 & 2 & .019 & .040 & 0.96 \\
\hline & 5 & $\begin{array}{l}\text { Crisis management and the } \\
\text { ability to make decisions }\end{array}$ & .041 & 2 & .020 & .045 & 0.96 \\
\hline \multirow[t]{5}{*}{ Error } & 1 & Communication & 78.02 & 222 & .351 & & \\
\hline & 2 & planning and Organization & 99.58 & 222 & .449 & & \\
\hline & 3 & $\begin{array}{l}\text { Development, adaptation, } \\
\text { flexibility and teamwork }\end{array}$ & 102.79 & 222 & .463 & & \\
\hline & 4 & Thinking skills & 104.97 & 222 & .473 & & \\
\hline & 5 & $\begin{array}{l}\text { Crisis management and the } \\
\text { ability to make decisions }\end{array}$ & 101.08 & 222 & .455 & & \\
\hline \multirow[t]{4}{*}{ Total } & 1 & Communication & 79.06 & 227 & & & \\
\hline & 2 & planning and Organization & 101.30 & 227 & & & \\
\hline & 3 & $\begin{array}{l}\text { Development, adaptation, } \\
\text { flexibility and teamwork }\end{array}$ & 105.71 & 227 & & & \\
\hline & 4 & Thinking skills & 107.35 & 227 & & & \\
\hline
\end{tabular}




\begin{tabular}{|l|l|l|l|l|l|l|l|}
\hline & 5 & $\begin{array}{c}\text { Crisis management and the } \\
\text { ability to make decisions }\end{array}$ & 106.29 & 227 & & & \\
\hline
\end{tabular}

Statistically significant at $(\alpha=0.05)$

Table 12 indicate that there are statistically significant differences at $(\alpha=0.05)$ in the last three domains of soft skills, (development, adaptation and flexibility, thinking skills, crisis management and decisionmaking) according to gender variable, as $\mathrm{F}$ values reached $(4.295,4.955,10.561)$ respectively, which are statistically significant values at the level of $(\alpha=0.05)$, it is also observed that the score means of females $(3.80$, $3.91,3.85)$ outperformed those of males $(3.71,3.78,3.77)$ respectively.

\section{Discussion}

The first research question of the study sought the degree to which primary school teachers in Amman Governorate possess soft skills in light of Corona virus pandemic from their principals' perspectives. The average response of the study sample on the scale as a whole was high with a mean score of (3.77), and a standard deviation of (0.62).

The result might be attributed to the novelty of this type of skills that primary school teachers should possess, moreover, having these soft skills is considered one of the basics that employers look for in job applicants, especially educational and administrative jobs that require dealing with students, which made teachers keen to possess them.

Furthermore, the policy for teacher education in the ministry of education is designed to develop a teaching profession ready and able to meet the needs of the 21 st century. The overriding aim of the policy is to properly equip teachers to undertake their essential and demanding tasks, and enable them to continually enhance their professional competence and performance.

The researchers believe that most of the sample members are teachers, who are the essential drivers of a good quality education system, and have possessed modern and necessary skills to be qualified for their jobto carry out their educational burdens in the best way, which might explain the high degree of possessing soft skills.

Besides, the ministry of education has made tangible efforts in qualifying and training pre- service teachers, which may led to their acquisition and possession of soft skills. The result seems to be in line with the results of [20] [18] [17] who asserted the importance of soft skills for teachers performance.

The second question sought if there are any statistically significant differences at $(\alpha=0.05)$ in the degree to which science teachers in Amman governorate possess soft skills from the viewpoint of their principals due to variables (gender, years of experience and their interaction). The results revealed the existence of gender differences on the last there domains of soft skills in Table 12 (development, adaptation and flexibility, thinking skills, crisis management and decision-making) in favor of female teachers may be attributed to the following:

Development, adaptation and flexibility: the female superiority in this regard may be attributed to the fact that females are more committed and willing to perform work, develop and pay attention to teaching process than males because they are already mothers who have a sense of caring for their children, making them survive, and giving them the chance to reproduce. So through natural selection, women of today's society are more likely to have traits such as caring and therefore they naturally proceed in professions such as teaching, since they are more caring and passionate about raising kids. This is the key responsibility they perform at home which has honestly become part of their lifestyle. Furthermore unlike men, they have great patience and they exercise restraint when they relate with studentswho are drawn to them because of this.

Regarding thinking skills, females may have the ability to influence others and think critically to provide creative ideas and solutions to problems, manage crises and likely to perform well even under difficult circumstances. This is what employers prefer because no one wants to hire who is unable to manage stressful situations and work under pressure. This seems to be consistent with [19]. And [15]. and differs from [22] who indicated that there were no significant differences attributed to gender variable.

There were no statistically significant gender differences in communication, planning and organization domains, the result might be attributed to the fact that both male and female teachers deal with students and teaching profession on a daily basis, accordingly, possessing communication, planning and organization skills constitute a basic building block in dealing with students, implementing tasks and duties and reaching the planned results. This result goes in line with the finding of [22] [23].

Table 12 also indicated that there were no statistically significant differences at $(\alpha=0.05)$ in soft skills according to the experience variable. This means that the degree to which primary school teachers possess soft skills from the viewpoint of their principals does not differ according to the years of experience. This result can be attributed to the fact that the study members, regardless of their years of experience, know very well how important it is to have soft skills to increase their productivity, build professional relationships, and thrive in their jobs. 
Additionally, and over the past decade, teachers have been subjected to pre-service teacher courses, which made them convinced of the significance of soft skills at workplaces, the enormous value they carry and their highly vital and valuable role for the present.

This result can also be related to the fact that primary school teachers have commonalities affected the degree to which they possess soft skills. They have undergone similar pre-service courses, and therefore the experience factor does not affect them, this result is consistent with the (Aladwan, 2014), who indicated that there are no significant differences for the experience variable.

Table 12 also indicated that there were no statistically significant differences at $(\alpha=0.05)$ in soft skills attributed to the interaction between gender and experience, since no difference between mean scores appeared on the degree to which primary school teachers possess soft skills.

This means that the two variables (gender, experience) are not interacting, and independent, which mean that the levels of one will not be affected by changing the levels of the other.

\section{Conclusion}

The findings of the study are expected to provide potentially significant information on the importance of soft skills that teachers possess, and the role of soft skills in keeping pace with developments, improving school performance, supporting teaching practice and providing effective strategies and techniques during teaching and learning process. Soft skills may also contribute to the development of workers' especially primary school teachers, furthermore, and based on the results of the current study, the researchers recommend the following:

- $\quad$ Encouraging primary school teachers to possess and practice soft skills.

- Developing soft skills of primary school teachers across different types of programs, courses and workshops.

- $\quad$ Applying clearly, specified and realistic standards for getting a job, the most important of which is possessing the necessary soft skills, as a condition of employment.

Ensuring that primary school teachers possess soft skills by holding objectively designed field tests aiming at developing and overcoming weaknesses.

\section{References}

1. Hysa. E. (2014). Defining a 21st Century Education: Case Study of Development and Growth Course to new century. Journal of Educational and Social Research 3(7), 704.

2. Vandenbroucke, L., Spilt, J., Verschueren, K., Puccini, C., \& Baeyens, D. (2018). The classroom as a developmental context for cognitive development: A meta- analysis on the importance of teacher-student interactions for children's executive functions. Review of Educational Research, 88 (1): 125-164.

3. Hefni, M. (2015). 21st Century Teacher Skills. Working Paper, Faculty of Education, Assiut University, Egypt.

4. Abualrob. M. (2019). The Role of Science Teachers in Developing the 21st Century Skills for the Elementary School Students, Interdisciplinary. Journal of Environmental and Science Education, 15 (1), 1-8.

5. Obaih, S. Saleh, A. (2020). Evaluating the experience of distance education in light of Covid19 from the point of view of students, a case study at the University of Ghardaia in Algeria, Journal of Studies in the Humanities And social 3 (3) , 42-62.

6. Distance learning system (2020). Retrieved on 10/30/2020 from the site http I/: www.moe.gov.jo

7. Vivek, G. (2020). Digital Education Transformation: A Pedagogical Revolution. Journal of Educational Technology, 17 (2): 66-82

8. Khamis, A. (2013). The soft skills they are looking for. Amman: Al-Roya Foundation for Press and Publishing.

9. Sweilem, F. (2013). Soft skills. Personal qualities put their owners at the forefront of the Employment Marathon: Sultanate of Oman: Alro'ya for Press and Publishing.

10. Investopedia. (2014). Hard \& Soft skills. Retrieved from: http://www.investopedia.com/terms/s/soft-skills.asp

11. White, M. (2012) The Real Reason New College Grads Can't Get Hired", Research in Higher Education, 53(4)4, 383.

12. Rao, M. (2014). Enhancing employability in engineering and management students through soft skills", Industrial and Commercial Training, 45(1): 42 - 48. Retrieved from: ttp://dx.doi.org/10.1108/ICT-04-2013-0023 
13. Robles, M. (2012). Executive Perceptions of the Top 10 Soft Skills Needed in Today's Workplace.

14. Kojak, K. (2008). Diversifying classroom instruction. A teacher's guide to improving teaching and learning methods in schools in the Arab world: UNESCO Regional Office in the Middle East.

15. Al-Dossary, M. (2016). The reality of using electronic educational platforms by faculty members in teaching English at King Saud University. Unpublished MA thesis, Yarmouk University, Irbid, Jordan.

16. Nganga, T., Yunusa, H \& Hashima, H. (2015).Soft Skills Integration in Teaching professional Training: Novice Teachers' Perspectives. Procedia - Social and Behavioral Sciences 186, 835 $-840$.

17. Schulz., B. (2008). The Importance of Soft Skills: Education beyond Academic Knowledge.

18. Vijayalakshmi, S (2011), Soft Skills - A Management Introspect of an Indian Techie, International Journal of Scientific \& Engineering Research, 2 (7): 229-277

19. Salim, S. (2012). The degree to which the academic leaderships in Jordan universities master soft skills. Unpublished MA thesis, University of Jerash, Jordan.

20. Tyagi, T; Ashu, K. (2013). Soft Skills for Successful Career, Pertanika Journal, Social Sciences \& Humanities, 21 (1): 341-350.

21. Quinley, K. (2013). How Soft Skills Complement Tech Fluency.

22. Aladawn, W. (2014). Soft skills of government school principals in the Education Directorate of Southern Shuna District. Unpublished MA thesis, University of Jerash, Jordan.

23. Shobir, R. (2016). Soft skills and their relationship to the entrepreneurial tendencies of students of technical and vocational colleges in Gaza governorates. Unpublished MA thesis, Islamic University, Gaza. 